\title{
Bedside Manners: Sickness and the Jesuit Mission in Early Modern New France
}

\author{
Mary Dunn \\ Saint Louis University \\ Mdunn12@slu.edu
}

\begin{abstract}
Situated in the original context of their composition, the Jesuit Relations illuminate something not just of Jesuit discourse as Thomas Worcester has argued, but Jesuit practice too, revealing the ways in which sickness and disease functioned as missionary strategy in New France. In the deft hands of the Jesuits, sickness and disease were opportunities for the conversion of the dying, occasions for the practice of Christian virtue, and invitations for dramatic displays of divine power. It was the sickbed that called both for the cultivation of patience, constancy, and holy resignation among the suffering sick and for the practice of charity among those who tended them. Moreover, it was at the bedside of the sick and the dying where the most eloquent arguments in defense of the Christian faith were made, giving sound evidence of the omnipotence of the Christian God.
\end{abstract}

\section{Keywords}

Jesuit Relations - Jesuits - missions - New France - sickness - infirmity - virtue - cure

Reporting on the mission of Saint-Jean Baptiste at Onnontagué in June of 1670, Jesuit Father Pierre Millet admitted that he had begun to "declare myself openly against" indigenous healers - known variously to the French as sorcerers, soothsayers, jugglers, and charlatans, inter alia. "I tried to bring them into disrepute on all occasions," he wrote, proceeding to describe to his superior in Quebec an exemplary incident involving a missing teenage girl and the "sorcerers" who had been summoned to find her.

(C) MARY DUNN, 2018 | DOI:10.1163/22141332-00504005

This is an open access article distributed under the terms of the prevailing CC-BY-NC license at the time of publication. 
"These clever Diviners," Millet began, "put their sorcery in operation, to learn some news of her." It was, in Millet's eyes, quite a show, complete with leaping, dancing, limb-shaking, drumming, singing, and heavy perspiration. Having pretended to "consult and question their Demon" about the missing girl, the jugglers at length "boldly declared that she had been killed by three Andastoguez, who had scalped [...] [and that] she had died precisely at Sunrise." With this news, naturally, the girl's parents and kin were distraught. But while the cabin resounded with "weeping and lamentations," the jugglers, unruffled, dug into the feast that had been prepared for them. Millet looked on scornfully, critical of appetite for gain so shamelessly displayed by these impotent healers. Millet's read of the jugglers as liars, frauds, cheats, and devil-worshippers must only have calcified when, shortly after the jugglers left, the missing girl herself came home unscathed. ${ }^{1}$

Stories like these are common in the Jesuit Relations, those mid-seventeenthcentury journals compiled by the Jesuits in New France and published in Paris for a readership eager for details of the progress of the Canadian mission. To the Jesuits laboring among the indigenous peoples of eastern Canada, traditional healing practices were nothing but "trickery," "charlatanry," and "superstitious science" undertaken by "imposters," "liars, and cheats" for personal gain and prestige and without any "virtue [or] natural efficacy." 2 Against the deceitful, self-serving, and ineffective curative interventions proffered by native healers, the Jesuits represented their own therapeutic treatments as honest, charitable, and efficacious. If the jugglers pretended that their remedies "not only restore the sick to health, but also raise the dead to life," the Jesuits were careful to acknowledge the limits of their capabilities. ${ }^{3}$ If the jugglers sought "generous presents and good pay" for their services, the Jesuits demanded nothing for theirs. ${ }^{4}$ If the therapies prescribed by the jugglers were "vain and useless," "more suited to kill than to cure a sick man," the remedies offered by the Jesuits proved invariably restorative-if not for the body then for the soul whose health was guaranteed by the sacrament of baptism. ${ }^{5}$

And it's not just episodes of conflict between Jesuits and jugglers that appear so frequently in the pages of the Relations, but, more broadly, stories

1 Reuben Gold Thwaites, ed., The Jesuit Relations and Allied Documents, 73 vols. (Cleveland: Burrows, 1896-1901), 53:287-91.

2 Ibid., 291; 10:197; 39: 19; 3:119, 115; and 8:121.

3 Ibid., 42:171.

4 Ibid., 8:121.

5 Ibid., 39:19 and 35:239. See also, 52:182 where Father de Carheil blames eat-all feasts for causing rather than remedying sickness and 68:59, where he suggests that indigenous methods of bleeding the sick have "crippled many." 
of sickness and healing, death and disease. The ailing and infirm are everywhere in the Relations: in the Relation of 1637 , for example, "sick" or "sickness" alone appear 132 times. But why? Why is it that the suffering bodies of the sick and the dying take up so much space in the Relations? What, in short, had sickness and healing, death and disease to do with the progress of the Canadian mission, and why, in the context of a mission oriented (or so it would seem) toward spiritual ends, did corporeal services account for so much of Jesuit activity?

The subject of sickness in the context of the Jesuit missions has received surprisingly little scholarly attention, although there has been substantial work on disease and depopulation in the Americas that necessarily touches on the Jesuits and a modest engagement with Jesuit attitudes toward sickness and disease. ${ }^{6}$ The most sustained treatment of sickness in the particular context of the Canadian mission is Thomas Worcester's 2005 essay, "A Defensive Discourse: Jesuits on Disease in Seventeenth-Century New France." Contextualizing the Relations in the mid-seventeenth-century climate of Jesuit vulnerability to both Gallican and Jansenist foes, Worcester frames these reports from the mission field of New France as a "defensive discourse." Taking the prevalence of sickness and disease as an intractable fact of the Canadian mission, Worcester is less interested in why the Jesuits write so much about the subject, and more interested in how the Jesuits write about it. The Jesuits, Worcester argues,

6 For examples of scholarship that directly addresses sickness and healing in the context of Jesuit missions, see Rebecca Crocker, "Healing on the Edge: The Construction of Medicine on the Jesuit Frontier of Northern New Spain," Journal of the Southwest 56, no. 2 (Summer 2014): 293-318; Steven J. Harris, "Jesuit Scientific Activity in the Overseas Missions," Isis 96, no. 1 (March 2005): 71-79; and Allan Greer, ed. The Jesuit Relations: Natives and Missionaries in Seventeenth-Century North America (Boston: Bedford/St. Martin's, 200o), 70-93. On disease and depopulation in the Americas, see Noble David Cook, Born to Die:Disease and New World Conquest, 1492-165o (New York: Cambridge University Press, 1998); Daniel T. Reff, Disease, Depopulation, and Culture Change in Northwestern New Spain, 1518-1764 (Salt Lake City: University of Utah Press, 1991); Eric E. Jones, "Spatiotemporal Analysis of Old World Diseases in North America, 1519-1807," American Antiquity 79, no. 3 (July 2014): 487-506; and Gary Warrick, "European Infectious Disease and Depopulation of the Wendat-Tionontate (HuronPetun)," World Archeology 25, no. 2 (2003): 258-75. On early modern Jesuit perspectives on sickness and disease, see A. Lynn Martin, Plague?: Jesuit Accounts of Epidemic Disease in the Sixteenth Century (Kirksville, mo: Sixteenth Century Journal Publishers, 1996) and Thomas Worcester, "Plague as Spiritual Medicine and Medicine as Spiritual Metaphor: Three Treatises by Étienne Binet, S.J. (1569-1639)," in Piety and Plague: From Byzantium to the Baroque, ed. Franco Mormando and Thomas Worcester (Kirksville, mo: Truman State University Press, 2007), 224-36.

7 Thomas Worcester, "A Defensive Discourse: Jesuits on Disease in Seventeenth-Century New France," French Colonial History 6 (2005): 1-15. 
"used accounts of disease in Canada as an opportunity to vindicate themselves and their closeness to God," representing sickness as an opportunity for the display of patience, disease as the occasion for virtuous charity, suffering as the stimulus of spiritual growth, epidemic as the catalyst of death-bed baptisms, and miraculous cures as evidence of divine favor. ${ }^{8}$ For Worcester, understanding the Relations as polemical discourse situates them "in the original context of their publication." 9

Worcester is, of course, right to remind readers of the political and ideological context within which the Relations were published and received-and right, too, to remind readers that the Relations are not innocent, objective, and unencumbered by special interests and agendas. ${ }^{10}$ The fruit of collaboration between Jesuits in the field (who supplied the first-person accounts), their superior in Quebec (who collated and culled these accounts into a single comprehensive report), and the French provincial (who applied his heavy editorial hand to the text "with current conditions in Europe in mind"), the Relations were published annually between 1632 and 1673 for a French audience. ${ }^{11}$ Given evidence of second and even third editions, the Relations were popular, appealing to a diverse readership that included not just the devout and the philanthropic on whose generosity the mission famously depended, but also those interested in colonial politics, markets, and the curiosities of the New World. Situating the Relations in the particular context of their publication and reception in France invites us to read these texts, as Worcester does, as outward-facing discourse - as texts written by the Jesuits, about the Jesuits, in the interest of creating and maintaining a Jesuit reputation in the metropole. But there is an inward dimension to the Relations, too. At least as much as the Relations tell us about the situation of the Jesuits in France, they tell us about the Jesuits in New France, too - their beliefs, their practices, their experiences, their strategies, their triumphs, their disappointments. Although I do not doubt that the Jesuits - particularly the provincial in France who had final editorial control over each installment—-had the Jansenists and Gallicans

$8 \quad$ Ibid., 3 .

9 Ibid., 11.

10 Many have wrestled with the reliability of the Jesuit Relations as objective history, particularly as a source of ethnohistory. See, for example, Micah True, Masters and Students: Jesuit Mission Ethnography in Seventeenth-Century New France (Montreal: McGill-Queen's University Press, 2015) and Erik R. Seeman, "Reading Indians' Deathbed Scenes: Ethnohistorical and Representational Approaches," The Journal of American History 88, no. 1 (June 2001): 17-47.

11 Lawrence C. Wroth, "The Jesuit Relations from New France," The Papers of the Bibliographical Society of America 30 (1936): 110-49, here 118. 
in mind when composing the Relations, to reduce these texts to an outwardfacing polemical discourse is to overlook the (perhaps all-too-obvious) value of the Relations as a resource on the mission itself.

It is, then, not as a replacement for but a supplement to Worcester's interpretation of sickness and disease in the Jesuit Relations that I offer the following argument: Situated in the original context of their composition (to invert Worcester's interpretative lens), the Relations illuminate something not just of Jesuit discourse, but Jesuit practice too, revealing the ways in which sickness and disease functioned as missionary strategy in New France. ${ }^{12}$ In the deft hands of the Jesuits, sickness and disease were opportunities for the conversion of the dying, occasions for the practice of Christian virtue, and invitations for dramatic displays of divine power. It was the sickbed that called both for the cultivation of patience, constancy, and holy resignation among the suffering sick and for the practice of charity among those who tended them. Moreover, it was at the bedside of the sick and the dying where the most eloquent arguments in defense of the Christian faith were made, giving sound evidence of the omnipotence of the Christian God who, repeatedly throughout the course of the Canadian Jesuit mission, brought the dying back to life to "the astonishment of all."13

Throughout the course of the mission's history, the Jesuits were well-knownsometimes notoriously so-for seeking out the ailing and the infirm with the intention of baptizing the dying while there was still time. ${ }^{14}$ Jesuit fathers like

12 I am not the first to argue that disease facilitated Jesuit success in the Americas. A number of scholars have pointed to the demographic devastations wrought by germs imported from Europe as a leading factor in stimulating indigenous conversions to Christianity. Rebecca Crocker, for example, building on the work of Margarita Kay and Daniel Reff, argues that the Jesuits' relative immunity to imported diseases and the comparative efficacy of European remedies against familiar microbes, as well as a missionary willingness to fill the power vacuum left by mass indigenous deaths, contributed to the success of the Jesuit mission in Sonora. My argument, however, is slightly different than Crocker's. I am less interested in the ways in which the demographic effects of disease paved the way for missionary victories and more interested in the ways in which Jesuits mobilized sickness and disease as the handmaid of the mission. See Crocker, "Healing on the Edge."

13 Thwaites, Jesuit Relations, 40:243.

14 Deathbed baptisms are a well-noted feature of the early Jesuit mission in New France. See, for example, Erik R. Seeman, The Huron-Wendat Feast of the Dead: Indian-European Encounters in Early North America (Baltimore: Johns Hopkins University Press, 2011), 
Charles Garnier wandered the villages, offering both spiritual and material assistance to the sick in the hopes of "discrediting [...] [the] sorcerers with their imaginary treatments" and leading "these poor people even to the gate of Paradise." ${ }^{15}$ In times of both general health and contagious epidemics, the Jesuits "made the rounds of the cabins incessantly," occupying themselves in the capacity of physician priests. "This is the order that we maintained," wrote Joseph le Mercier in 1637, describing the Jesuit response to an epidemic that had ravaged a mission village: "We visited [the sick] twice a day, morning and evening, and carried them soup and meat, according to the condition and disposition of the patients-always taking occasion to exhort them to have recourse to God, and to gently influence them to Baptism."16

In focusing their efforts on the baptism of the moribund, the Jesuits were hedging their bets, conferring the sacrament only upon those least likely to apostatize. Writing on the mission of Saint Jean Baptiste at Onnontagué in 1674, Jean de Lamberville explained that "it is dangerous to administer baptism to [those] who are not sick [...] lest they might, later on, profane it by [...] infidelity."17 Already by the 1630s, however, the Jesuits' careful solicitude for the sick and commitment to baptizing the dying had led some natives to conclude that the Jesuits themselves were the authors of bodily affliction and baptism the harbinger of death. If the baptism of the dying was a missionary strategy, it was one destined for misinterpretation. In the eyes of a witnessing indigenous population, the relationship between baptism and death looked like one of cause and effect, and the Jesuits like enemies out to harm the bodies of the living rather than friends hoping to save the souls of the dying. It was, in part, because of the suspicion that the sacrament would hasten a loved one's demise that Jesuits ministrations toward the sick and the dying were sometimes met with determined resistance, as in the case of "a woman of Tsonnontouen who had been ill for nine or ten months." Convinced, like her compatriots, that "the Faith and Baptism [...] served only to hasten the time of their death," the woman refused to let Father de Carheil approach her, regarding him "as a man who was infected and who carried a deadly poison about with [him], which [he] breathed into people through their eyes and ears."18 In other cases, it was

52-58; Emma Anderson, The Betrayal of Faith: The Tragic Journey of a Colonial Native Convert (Cambridge: Harvard University Press, 2007), 154-55; and Alain Beaulieu, Convertir les Fils de Caïn:Jésuites et Amérindiens nomades en Nouvelle-France, 1632-1642 (Quebec: Nuit Blanche Éditeur, 1990), 89-132.

15 Thwaites, Jesuit Relations, 15:67 and 35:131.

16 Ibid., 13:111.

17 Ibid., 58:215-17; see also, 11:137.

18 Ibid., 54:55-57. See also, 15:67-69 where the Jesuits are accused of caring "for only the sick and the dead." 
not the patient herself who resisted baptism, but her or his kin, forcing the Jesuits to catechize and baptize the sick "without appearing to do so."19 As late as 1674, Father de Lamberville found himself compelled to baptize a dying child "without the knowledge of his parents" who feared that this child, too, would die after baptism just like his sister before him. ${ }^{20}$

If sickness and disease - which, by all accounts, were salient features of the seventeenth-century Canadian landscape-provided opportunities for the deathbed baptisms that constituted many of the mission's early gains, they also gave occasion for acts of Jesuit charity. ${ }^{21}$ I will return to the didactic function of charity in the Canadian mission below. Here, however, I want to highlight the ways in which the "temporal assistance" the Jesuits rendered to the sick and the dying worked, over time, to weaken the connection between baptism and death and moved some indigenous Americans to actively request the sacrament. ${ }^{22}$ Take, for example, the way medicine worked in the case of an Iroquois from Agnié who had been suffering for "a long time [from] an inflammation of the lungs which gave him no respite." ${ }^{23}$ Intending "more to win his affection than to procure him an entire cure," Father Bruyas gave the man the only medicine he had left and proceeded to exhort him to repent and convert in the little time remaining to him. The man softened, asked for further instruction, and was baptized on his deathbed, surviving "but a Baptism [...] served [but showing] so great fervor and devotion" that Bruyas was almost made speechless. ${ }^{24}$

The modest medicines distributed by the missionaries - the ointments, the raisins, the prunes-worked "little miracles" in New France, restoring health to both bodies and souls and persuading those who, before, had concealed the sick to now confide them to the Jesuits. ${ }^{25}$ Moreover, it was not just pharmaceuticals, however primitive, that won the confidence of the indigenous sick, but the compassionate attention shown by the Jesuits to the ailing and the infirm. In vivid contrast to what looked to the missionaries like the deliberate

19 Ibid., 17:189. See also, 58:217-19.

$20 \quad$ Ibid., 64:163.

21 On disease in early Canada, see Warrick, "European Infectious Disease"; Dean R. Snow and William A. Starna, "Sixteenth-Century Depopulation: A View from Mohawk Valley," American Anthropologist 91, no. 1 (March 1989): 142-49; Bruce Trigger, "Ontario Native People and the Epidemics of 1634-40," in Indians, Animals, and the Fur Trade: A Critique of Keepers of the Game, ed. Shepard Krech, III (Athens, GA: University of Georgia Press, 1981), 19-38; and Allan Greer, The People of New France (Toronto: University of Toronto Press, 1997), 18-26.

22 Thwaites, Jesuit Relations, 8:147.

23 Ibid., 51:227.

24 Ibid., 51:227-29.

25 Ibid., 62:93. 
neglect of the infirm, Jesuit charity spoke powerfully among the native peoples of eastern Canada. Repeatedly throughout the Relations, Jesuits drew attention to the baffling indigenous custom, observed across the mission field, of abandoning the sick and the dying. Native Canadians, it was noted, "readily despair of the sick, and neither provide them with food nor care for them in any way. ${ }^{26}$ Literal burdens to a nomadic people whose survival depended on mobility, the ailing and the infirm were, the Jesuits tell us, "looked upon as beings of another world, with whom is held no intercourse, no conversation," deserted to the natural process of life's decline. ${ }^{27}$

Into this vacuum of care the Jesuits readily slipped, nursing the sick back to health, providing comfort to the dying, and prompting some indigenous observers to conclude "that it was a good thing to be a Christian, since the black gowns [...] assisted, even unto death, those who had loved prayer." ${ }^{28}$ To Jesuits like Father Buteux, sickness and disease were occasions for charity and charity the occasion for the salvation of souls. Finding himself in the company of a "paralytic woman" who was covered only "with a quarter of a very meager and worn-out blanket" and exposed to the open air on all sides which left her "sometimes all stiff and frozen with the cold," Buteux got to work. He fed his grateful patient "like a child" and instructed her in the mysteries of the Christian faith - although, in the end, the woman was put to death by her own kin just a few days after her baptism. ${ }^{29}$ The fate of a young Huron man was better. Having been dragged into the woods by his relatives where he was often "left all alone" with little to eat, the man was at death's door when the Jesuits found him and "succored him so effectually that this carcass again became a body." The man recovered completely and now, Father le Jeune happily reported, "preaches to his own people, reproaching them for their vices and their ingratitude with a freedom that consoles us." ${ }^{30}$

Without first-person testimony, it is impossible to say why indigenous Americans like these were persuaded by the "eloquence" of charity to convert to Christianity. ${ }^{31}$ It is reasonable to suspect, however, situating these reports

26 Jesuits in Sonora, like Jesuits in New France, accused native Americans of abandoning their sick. Crocker suggests that the Sonoran Jesuits may have misapprehended native intentions, interpreting an unwillingness to usurp the healing authority of the shaman for indifference toward the sick and the dying. Crocker, "Healing on the Edge," 306.

Thwaites, Jesuit Relations, 16:23.

28 Ibid., 57:113. The charity practiced by the nuns of the Hôtel-Dieu had much the same effect. See, 22:167, 25:119-21, and 41:229-31.

29 Ibid., 11:107-9.

$30 \quad$ Ibid., 14:151.

31 Ibid., 49:81. 
within the broader context of what we know about indigenous culture in eastern Canada, that the ethic of reciprocity played some role. As historians like Denys Delâge and Daniel Richter have long noted, social and spiritual relationships among indigenous Canadians were structured according to the rule of give-and-take, by which gifts given were to be compensated in kind. ${ }^{32}$ So, when indigenous Americans like the paralytic woman and the young Huron man above found themselves on the receiving end of Jesuit ministrations, it is reasonable to suspect that they felt themselves obligated to give something in return - whether a willing ear or their consent to be baptized.

The organizing principle of reciprocity, moreover, seems to have stimulated not just conversions made in gratitude for services rendered, but conversions rooted in a genuine conviction in what the Jesuits preached about post-mortem judgment and life in the next world. Brought to the Hôtel-Dieu to receive treatment for a wound,

a Savage who was very headstrong and much opposed to the Faith [...] was so filled with surprise and wonder at seeing the gentleness, the goodness, the modesty, and the charity of those good Mothers that he did nothing but exclaim over and over again: "Why, what do these girls mean? What do they expect from those sick people who have nothing?" They give their food, their means, their labor, with so much kindness; and they are given nothing in return! They must certainly hope for other blessings after this life. ${ }^{33}$

To an indigenous population grounded in the ethic of reciprocity, the generosity of the Jesuit fathers and the Hospitaller mothers was a gift that must necessarily generate a return. If they refused to accept payment from the sick and their kin, then they must necessarily expect as a reward for their charity "eternal life from God."34 Such logic was enough to convince at least one "good Huron woman" to take Jesuit teachings as "infallible truth" and another, who, not yet disabused of the notion that baptism hastened death, to believe

32 Denys Delâge, Bitter Feast: Amerindians and Europeans in Northeastern North America, 1600-1664, trans. Jane Brierley (Vancouver: U вс Press, 1993), 52. See also, Daniel K. Richter, The Ordeal of the Longhouse: The Peoples of the Iroquois League in the Era of European Colonization (Chapel Hill: University of North Carolina Press, 1992), 47-49; and Melissa Pflug, "Pimadaziwin: Contemporary Rituals in Odawa Community," in Native American Spirituality: A Critical Reader, ed. Lee Irwin (Lincoln, NE: University of Nebraska Press, 2000), 121-44.

33 Thwaites, Jesuit Relations, 40:229-31.

34 Ibid., 49:77-79. 
nonetheless that the sacrament was "a good thing with which to protect oneself from the fires" of hell. ${ }^{35}$

Even if the association between baptism and death never disappeared entirely from the Canadian mission, over time, Jesuit ministrations toward the sick and the dying effectively attenuated the connection between the two events-so much so that many indigenous Americans came to seek out baptism in the conviction that the sacrament possessed curative powers. Despite the Jesuits' explicit (although perhaps disingenuous) disavowal of any connection between baptism and physical health, the unexpected recovery of so many converts convinced whole families that "those sacred waters not only do not cause death, as was formerly held, but even give health to the sick and restore the dying to life."36 The counterpoint to suspicions that baptism hastened death, the belief in the restorative capacities of baptism prompted even those Amerindians who cared "only for the world" to request the sacrament. ${ }^{37}$ Here, too, the ethic of reciprocity was at work: In exchange for the baptism that she trusted would beget her recovery, an ailing Huron woman promised to believe in the articles of the Christian faith (inverting the usual order of events by which belief preceded baptism). Although le Jeune tried to explain that curing her disease "was not in our power," the woman persisted and, at length, received the sacrament only to apostatize shortly before her death. ${ }^{38}$ Father Nouvel was more equivocal: in response to a Papinachois captain named $\mathrm{Ou}-$ iskoupi who attributed his own cure and the cure of his children to the healing powers of baptism, Nouvel carefully acknowledged that God is sometimes "so good that he gives to those who believe and have trust in him, more than they ask of him; and that Baptism, which is instituted to confer holiness upon the soul, often gives health to the body." ${ }^{39}$

35 Thwaites, Jesuit Relations, 49:77-79, and 11:83. The "good Huron woman" went on to explain that because the French offered their charitable services "without gaining anything in return except the Paradise which they expect as a reward," such services gave "proof which ought to convince us that we too are to win Paradise."

36 Ibid., 51:23. See also, 23:207 on how Algonkin parents, having perceived so many cures following baptism, brought their children to be baptized by the Jesuits as soon as they fell ill.

37 Ibid., 11:83.

38 Ibid., 11:109. Like le Jeune, a Huron convert also tried to disabuse his countrymen of the notion that baptism brought restoration of physical health. "Do not think," he cautioned at the bedside of his dying compatriot, "that the water of Baptism is poured out to heal thy body: it is to purify thy soul, and to give thee a life which cannot die. Baptism was not instituted for a thing so low as our life." Ibid., 20:201.

Ibid., 50:55. 
If, within the local context of the Canadian mission, sickness provided opportunities for the deathbed baptisms and "miracle[s] of charity" that constituted many of the mission's early gains, the sickbed also served as a site of instruction in Christian virtue. ${ }^{40}$ It was at the bedside of the sick and the dying that the Jesuits communicated powerful lessons about charity, patience, constancy, and holy resignation. Charity toward the sick and the dying was, as I have argued, a means of winning converts to the faith. But, enshrined by Paul in First Corinthians and refined by Aquinas in the thirteenth century as the sine qua non of Christian virtues, charity was also an end in itself, the hallmark of a truly Christian life. ${ }^{41}$ Among the sick and the dying, Jesuits like Father Bruyas found "an opportunity [for] practicing charity," as did indigenous converts like Charles Meiaskwat who dedicated himself to the care of the "poor and infirm," "taking [...] a singular pleasure in comforting them, and in speaking to them of God." ${ }^{2}$ The facts of sickness and disease operated within the context of the mission like a practicum within which the virtue of charity might be exercised, elaborated, and put into practice. It was the dire circumstances of two orphaned children (the one "afflicted in a frightful manner with scrofula on his neck" and the other beset by "a hemorrhage which was reducing her to a skeleton") that persuaded Antoinette Ouabistitecou, for example, to overcome the "savage" tendency to neglect the sick and to cultivate charity by washing the orphans, feeding them, and tending to their fire. ${ }^{43}$

If the sick and the dying offered to the Jesuits and their indigenous converts occasions for practicing the virtue of charity, their physical infirmities offered to the sick and the dying themselves priceless opportunities for the cultivation of patience, constancy, and holy resignation. The Relations - sounding a note in harmony with centuries of Christian hagiography—abound with stories of the exemplary virtue of converts like Lazare Petikouchkaouat, who "left us one of the rarest examples of patience that it is possible to see." Lazare spent seven months in the Hôtel-Dieu, "afflicted with very painful sores in several parts of his body, with a fever that continually preyed upon him and so parched him that he could not quench his thirst," and an insatiable appetite that did nothing to slow the progress of his wasting disease. Toward the end of Lazare's life, his bones "actually pierced through his skin" and his flesh began to rot. It is true, admitted the Mother Superior, that Lazare "suffered strangely," but his

\footnotetext{
$40 \quad$ Ibid., 8:99.

41 See, 1 Cor 13 and Aquinas, Summa theologica, 2.23-26.

42 Thwaites, Jesuit Relations, 57:81; 24:55.

43 Ibid., 41:193.
} 
astonishing "patience [was] still more strange." ${ }^{44}$ Indeed, the more extreme the suffering, the richer the opportunity for the cultivation of virtuous patience. Another convert, only sixteen years old, presented a similar example of "patience of iron" in the midst of unimaginable agony. Suffering from an abscess in his head, this boy "became paralyzed; his poor body began to rot before being in the ground; worms came out of his ears; his skin was all torn, and his limbs were falling away almost piecemeal." Unable to "be moved, or turned, or touched without suffering extremely [...] [the boy] had only enough sense to suffer patiently, and to pray to God." 45

Sickness and disease also granted indigenous converts the opportunity to prove their constancy vis-à-vis their newly adopted faith, particularly in the face of the temptations presented by traditional culture. Emery Tchames, whom "God tried [...] by means of an illness that gave him occasion to fortify himself in the Faith," was hardly exceptional among neophytes. One night the ailing Emery had a dream in which he was counseled to "prepare an eat-all feast [...] [to] put Eagles' feathers on thy body... [and to] pray no more [...] [for] it is prayer that has made thee ill." Emery, however, resisted the impulse to obey what his dream had revealed to him, substituting for a traditionalist faith in dreams a convert's faith in God. "No matter if I have to die," he declared, "I will never return to what I have abandoned [...]. Even if I saw death before my eyes [...] I [would] be faithful to God, in life and unto death."46

To the Jesuits, the constancy of the sick and the dying was made evident not only in their habitual rejection of traditionalist treatments, but also in the strength of their devotion to the sacraments and the rituals of the faith. Even in the midst of a mortal illness, Sister Geneviève Agnes de tous les Saints "did not omit to sing one on each of the three days of holy Week [...] never [forgetting] her little prayers, least of all her Rosary, although her suffering was acute."47 Marie Oukiwichunoukwe, too, "never failed to perform her minor duties toward God, night and morning," although she "burned with a fire that devoured her tongue, her throat, and all her chest [so that] she became emaciated like a skeleton." ${ }^{48}$ And Marc-Antoine, consumed by a malady that had reduced him

44 Ibid., 19:13-15.

45 Ibid., 25:213.

46 Ibid., 22:223-25. Echoes of Emery's sentiment reverberate throughout the Relations, as in the case of a Huron woman who refused to send for the jugglers requested by her dying kinsman. "I would rather," the woman said to him, "see thee die, than that God be offended through my instrumentality." Ibid., 20:265. For similar sentiments, see 24:29 and 32:295-97.

47 Ibid., 44:265.

48 Ibid., 25:205. 
"to bones and skin," nonetheless prayed ceaselessly, complaining only that the nuns of the Hôtel-Dieu with whom he lodged did not demand enough of him. When his precious rosary "fell from him, or was misplaced, they had to turn the bed, and cabin upside down in order to find it."49

If anything, the constancy of the sick and the dying was too much. Repeatedly throughout the mission's history, the Jesuits found themselves in the position of trying to curb what they perceived as the excess piety of ailing converts. A captain's wife, suffering from a dangerous illness, "had to be absolutely forbidden" to come to mass - an obligation she took so seriously that "she would drag herself on the ground [...] lean upon a stick, or have herself carried by her daughter" - in order to preserve what health remained to her. ${ }^{50} \mathrm{On}$ another occasion, an anonymous Jesuit "met a very infirm Savage woman, who was coming to Mass in the midst of the snow." The Jesuit assured the woman that both the weather and her infirmity relieved her of the duty to go to church and cautioned her that if she continued, she would aggravate her disease to the point of death. The woman, however, insisted that she could not employ "what little life" she had left "better than in serving so good a Master" and explained that she no longer feared death anyway, eager to "enter into the joys of the other world." 51

In addition to patience and constancy, the infirmities borne by the sick and the dying also provided occasions for the cultivation of the virtue of holy resignation. Like the "very infirm" woman, the exemplary sick demonstrated a studied detachment toward both life and death —an indifference all the more remarkable given that "as a rule" indigenous Americans cared "only for the life of the body."52 In the context of their own suffering or the suffering of their kin, converts found opportunities to acknowledge God as the ultimate authority over life and death and to submit themselves to divine decree. Informed that "his life could not be saved," a sick man at the Hôtel-Dieu replied, "Well [...] my life is not at my own disposal; let him who has made all order it as he pleases; he is the Master of it." ${ }^{\prime 3}$ Repeatedly throughout the Relations, moreover, the Jesuits drew attention to converts who, having overcome their native attachment to temporal life, expressed not just a neutrality toward sickness and death, but a desire for them. In the conviction that God sent illness in order to "constrain [them] to have recourse to his goodness," some converts

\begin{tabular}{ll}
\hline 49 & Ibid., 20:167-69. \\
50 & Ibid., 26:85. \\
$5^{1}$ & Ibid., 32:235. \\
$5^{2}$ & Ibid., 58:59. \\
53 & Ibid., 22:163.
\end{tabular}


found themselves compelled to admit that "sickness is a good thing," capable of restoring health to the soul even as it afflicted the body. ${ }^{54}$ Others yearned for death, "anxious to be in Heaven where my heart assures me that God will reward me for my faith, and for the confidence that I have in him." 55

Sometimes, as in the case of a Huron man who watched his wife and daughter fall ill, God chose to reward demonstrations of holy resignation by restoring health to the unwell. The man instructed his wife and daughter to entreat God with a carefully crafted prayer, one that simultaneously acknowledged God's authority over life and death, delicately raised the possibility of healing, and a professed total submission to God's will. Offering them a little holy water, the man urged his wife and daughter to "lift up your hearts to God and say to him: 'Cure me, if it be thy will. Thou canst do all things. If thou say of me: "Let her be cured!" I shall be cured. If thou wilt not cure me, follow out thy own purpose. I do not believe in thee only that my health may be restored." To his wife's and daughter's supplications, the man added his own. "One of them," he reported, "was suddenly cured." 56 The other improved over time.

If sickness and disease provided opportunities for the cultivation of the Christian virtues of charity, patience, constancy, and holy resignation, they also gave occasion for dramatic displays of divine power as God intervened to restore physical health to the unwell-often suddenly (as in the case cited above) and to the astonishment of the witnessing public. The Relations fairly teem with stories of people cured by prayer of inflammation, fever, paralysis, bloody flux, pain in childbirth, jaundice, even deafness, muteness, and blindness. ${ }^{57}$ Sometimes the prayers offered by the sick or their kin hewed to the formula followed by the man above-a formula that united supplication to submission and seemed to be particularly effective in attracting divine attention. ${ }^{58}$ At other times, the sick and their kin appealed to God more directly, like

54 Ibid., 30:79. For similar sentiments, see 32:251, 39:139-41, 48:67-69.

55 Ibid., 36:203. For other instances of converts expressing a distaste for the world and an eagerness for life after death, see 22:161 and 14:167.

56 Ibid., 32:197.

57 Ibid., $55^{1115^{-25}}$.

$5^{8}$ Take, for example, the prayer offered by a man on behalf of his son Isaac. Isaac having fallen ill shortly after his baptism, his father "took him into his arms, brought him to the Church, made on his forehead the sign of the Cross with holy water, and presented him to God with these words: 'He is thine; take him, or give him back to me. Thou didst give him to me; do what thou wilt. Thou canst heal him; I believe in thee; have mercy on me." Much to the father's great pleasure, "no other medicine was needed for the healing of that child: he brought him back, full of life, into his cabin." Ibid., 35:243. For other prayers hewing to a similar formula, see 32:273-75 and 22:79. 
the grandmother of a boy named François who brought her feverish grandson to the Chapel near Lake Erie, explaining to Father Nouvel that she had "recourse solely to prayer for his cure." Her prayer was granted, Nouvel reported in the Relation of 1676, "for, after I had read a Gospel over [François] at the end of mass, he was completely cured; and on the following day I saw him, free from all sickness." 59

In a number of cases, prayer and the healing that followed gave opportunities to prove the illegitimacy of traditional jugglers and the efficacy of Christian remedies - or, writ large, the impotence of traditional deities and the power of the Christian God. The mother of an ailing child refused to accept the help of a juggler who had "presented himself to cure [the child] with his cries and yells," insisting that she would rather see her child die than have recourse to infidel remedies. The mother then turned to her fellow Christians and asked them to pray to God on behalf of the child. Our Lord, reported Jérôme Lalemant, "was pleased to grant to the faith of the parents the life and health of their child."60 In other cases, the curative properties of prayer won converts to the faith, as happened with a traditionalist man who had injured himself in a fall "while journeying over the ice of our great lake." The man's companion, a Christian, knelt down "in the midst of that icy plain" and entreated God to heal his friend. No sooner had the Christian finished praying than his companion "return[ed] to himself, and [rose], as vigorous as if his fall and his wound had been nothing but a dream." Thereupon, the man pledged to become a Christian and returned to the Jesuits "a good catechumen instead of a mischievous infidel." ${ }^{1}$

If prayer, undertaken in sincere sentiments of piety, wrought the restoration of health, prayer's counterpart-blasphemy—brought sickness and even death. In the autumn of 1647, an apostate named Joseph Oumosotiscouchie blamed the epidemic that ravaged his people on Christianity. Eventually he, too, succumbed to the disease and was dead in short order, "the drivel and foam issuing from both sides of his mouth." ${ }^{2}$ For the Jesuits, the apostate's untimely end was divine payback, punishment for not only apostatizing but also blaspheming the faith as the cause of sickness. Sometimes, as Father Allouez explained it, God chose to visit the sins of the father upon the son as happened when a man of the Potawatomi nation, having partially recovered from his illness "in consequence of [the] sacrament" of baptism, took a turn for the worse

\footnotetext{
59 Ibid., 6o:221-23.

6o Ibid., 32:297. See also, 45:59-61 and 55:123-25, 127.

61 Ibid., 30:115-17. See also, 55:117.

62 Ibid., 31:263.
} 
and died, "killed [...] by [the] impiety" of his father who "took it into his head to make a feast" for his son's recovery. ${ }^{63}$

It was not just prayer that persuaded God to heal the sick, but the sacraments of baptism and the Eucharist, too. Among these, baptism accounted for the most numerous cures, producing instant recoveries and prompting the healed to evangelize. Baptism, for example, unexpectedly healed a woman of the neutral nation who suffered from "illness which [had] reduced her to a very critical condition." After her cure, the woman was given "so high an opinion of the faith" and put "into so rare a fervor of devotion" that she always said the rosary while she walked and "served as an example even to the most fervent of that Church." ${ }^{4}$ God also worked to restore health to the unwell through the medium of the holy Eucharist, as happened in the case of a woman who had labored without success for two days to deliver her child. Finding the woman nearly done in by her acute suffering, the Jesuit at the mission village called all her neighbors together "to offer to God the sacrifice of his son." Within a few hours, the woman gave birth and was "free from pain and sickness." 65 Another time, it was the reception of the Eucharist that cured an ailing Algonkin who had been "overtaken by a sort of paralysis accompanied by extraordinary convulsions and nervous contortions." 66

Astonishing cures were also wrought through sacramentals like relics and holy water. One young boy, who had fallen into a swoon from which he would not awaken, was revived when the relics of Saint Francis Xavier were placed on his breast. Even the relics of colonial holy men who had died in the odor of sanctity but had not yet been officially canonized were effective. Father Nouvel, for example, healed a child of a serious disease by giving him "a little water in which I had dipped a relic of Father de Brébeuf's." ${ }^{67}$ Holy water alone-even without relics-worked wonders. A young man, "one of the greatest hunters and warriors in the country," was afflicted by a disease that caused him to become blind. He suffered thus for months until two missionaries arrived and, "exhort[ing] him to hope in God," applied "to his eyes some holy water, with a sign of the cross, uttering these words: 'May he whom you have taken for master, Our Lord - the Father, the Son, and the Holy Ghost, cure you."'68 In short order, the young man's sight returned.

\footnotetext{
63 Ibid., 51:39. For other stories of God punishing blasphemy or sin with sickness, see 32:4143; 51:109; and 7:287-89.

64 Ibid., 52:19.

65 Ibid., 32:277.

66 Ibid., 45:49-51.

67 Ibid., 56:101.

68 Ibid., 20:21-23. For another holy water cure, see 32:259-61.
} 
Finally, God's power was made manifest on the bodies of the sick through the media of the Virgin Mary and the saints. By 1674 (and the founding of the chapel at the Huron mission village of Notre Dame de Lorette), devotion to the Virgin Mary had become entrenched among the Huron Christian community. Just as she did for her European devotees across the Atlantic, the Virgin Mary intervened to restore health to the infirm in New France. Take, for example, a Frenchman (recently freed from captivity among the Iroquois) who suffered from a sore finger that, "despite the application of all the usual remedies," refused to heal. He was "ready to give himself up to vice and embrace the life of a Savage," when Father Le Moyne arrived. Le Moyne both tended the infected finger and prescribed "some acts of devotion to the blessed Virgin, which had so good an effect that in a few days he was rid of his temptation, and cured of the sore he had had on his hand for more than six months." Like so many others whose incredible cures were reported in the Jesuit Relations, the Frenchman's physical restoration was accompanied by a spiritual transformation that substituted for his habitual tendency toward vice a novel orientation toward virtue. No longer inclined toward "evil influences," the man thereafter employed his healed hand in "a most excellent service, using it to baptize children." 69 Something similar occurred in the case of Joseph Chiwatenhwa who recovered from a severe illness after the Jesuits invoked his patron saint on his behalf. Within two days of appealing to Saint Joseph, Le Mercier noted that Chiwatenhwa had recovered completely and resigned himself not only to stay faithful to God for the rest of his days, but also to "so act that the others will know it."70

So, what are we to make of stories like these-stories of exemplary virtue and miraculous cures? How, in the end, are we to read accounts of the selfless charity of neophytes like Charles Meiaskwat and the superhuman patience of converts like Lazare Petikouchkaouat? Are we to proceed with a hermeneutic of suspicion, wise to the interests and agendas that might have shaped Jesuit discourse on the mission? Or with a hermeneutic of sincerity, taking Jesuit reports as reflective of missionary practice? Are the Relations best understood as outward-facing polemic, directed against a hostile readership back home? Or as texts that face inward, revealing something of the lived realities of missionary experience?

\footnotetext{
69 Ibid., 47:201-3.

$70 \quad$ Ibid., 15:83. For reports of other cures through the medium of saints, see 50:119-21; 51:37; 27:47-49; and 29:167-69.
} 
Read as outward-facing discourse, the Relations' rhetorical emphasis on the charitable impulses of Christian converts and the extraordinary patience, unshakable constancy, and even-tempered resignation of the indigenous infirm functioned as an argument in defense of the depth and authenticity of native conversions. The elaboration of virtues like these, juxtaposed with ethnographic descriptions of traditionalist Amerindians as indifferent toward the sick and unduly attached to the things of this world, gave proof of just how deep indigenous Christian roots reached. It is surely no accident that the virtues the Jesuits found so admirable among the sick and the dying of New France-charity, patience, constancy, and holy resignation-resonated richly with those celebrated by centuries of Christian hagiography. ${ }^{71}$ To a motley French audience (composed of friends and enemies alike), the message was clear: these were no nominal converts, but true Christians whose conduct and general orientation to the world - tested in the fire of sickness and diseasehad undergone a radical transformation in the mold of the most laudable of Christian saints. The Jesuit mission was working.

Looking west, to the circumstances within which the Relations were published and received, it is easy to read Jesuit commentary on sickness and disease, as Worcester does, as polemic in defense of the Jesuit mission. It is easy to read accounts of sickness and disease as occasions for new baptisms, virtuous performance, and divine intervention as Jesuit attempts to "prove' divine approbation of Jesuit teaching and Jesuit activities." ${ }^{72}$ And, indeed, we overlook the polemical character of the Relations at peril of misapprehending these texts in context. But just as crucially, we risk misunderstanding the Relations if we assign too much weight to their polemical character to the exclusion of their multiple facets. Looking east, to the site within which the Relations were composed urges us to appreciate these texts as artifacts of not just Jesuit discourse, but Jesuit practice, too. Read with a sensitivity to their inward dimension, the Relations illuminate the ways in which the Jesuits harnessed sickness and disease to missionary ends, making use not just of sickness and disease as

71 Among seventeenth-century French hagiographies alone, those of Margaret Mary Alacoque, Claude La Colombière, and Vincent de Paul give excellent examples of the elaboration of these virtues in connection with sickness, disease, and death. See, Jean Joseph Languet, La vie de la venerable mere Marguerite Marie, religieuse de la Visitation Sainte Marie du monastere de Paray-Monial en Charolois, morte en odeur de sainteté en 1690 (Paris: J. B. Garnier, 1729); Louis Perroy, Le Pere Claude de la Colombière de la Compagnie de Jésus, 1651-1682 (Paris: P. Lethielleux, 1923); and Louis Abelly, La Vie du venerable serviteur de Dieu, Vincent de Paul, instituteur et premier superieur general de la Congregation de la Mission (Paris: F. Lambert, 1668).

72 Worcester, "Defensive Discourse," 11. 
opportunities to confer baptism on the dying, but of the sickbed as a didactic platform from which to impart critical lessons about the virtues of charity, patience, constancy, and holy resignation and the omnipotence of the Christian God.

If we attend too myopically to the outward-facing dimension of the Relations, to the context in which they were published and received, to the enthusiastic French readership that eagerly awaited each annual edition, we risk effacing the indigenous audience whose presence is remembered, albeit obliquely, in these Jesuit texts. For, the Relations were not just penned for the benefit of readers across the Atlantic, but as a record of events-however adapted for print - that took place before a witnessing indigenous public and, in the case of accounts of sickness and disease, on the failing bodies of the indigenous infirm. To recognize the ways in which the Relations disclose something of Jesuit practice is to enflesh these texts, to recover the bodies (both Jesuit and indigenous) at the heart of the Canadian mission. Attending to the ailing and infirm as not just rhetorical creations but embodied realities invites us to see how Jesuit treatments of sickness and disease functioned as missionary strategya strategy designed primarily with the intent to baptize, edify, and instruct indigenous Amerindians. 